\title{
自動車の自動運転の 実現と社会デザイン
}

自動車の自動運転について、社会の関心が高まっている。日本学術会議総合工学委員会・機械 工学委員会合同工学システムに関する安全・安心・リスク検討分科会では、「車の自動運転検討小 委員会」を組織し、この小委員会が中心となって、2017年6月に提言「自動運転のあるべき将来 に向けて一学術界から見た現状理解一」を発出した。その背景は、以下のとおりである。

昨今の自動車業界での自動運転に向けた活発な動きや、日本政府も自動運転車の開発口一 ドマップを公表するなど、自動運転に関するマスコミ報道が加熱している。一方で、交通事 故等の自動車交通の引き起こす負の側面はまだまだ解決せず、高齢化が進むことでより一層 深刻になる面も想定される中、自動運転に対する過度とも言える期待や誤解が散見される。 これらの状況を鑑み、正しい現状理解とあるべき将来に向けての議論を日本学術会議で行つ たので、それを提言としてまとめる。

この小委員会では、2018年7月の公開シンポジウムである安全工学シンポジウムでオーガナイ ズドセッションを企画し、その成果をべースに本誌の2019年9月号に「自動車の自動運転の研究 開発の現状と課題」という特集を組んだ。またこれと並行して、「自動運転は社会に対するインパ クトが大きいので、さらに広範囲の観点から自動運転や社会デザインについて検討する場が必要」 という認識から、日本学術会議では、2017年10月からの第24期において、「自動車の自動運転の 推進と社会的課題に関する委員会」を設置した。第23期の小委員会は、日本学術会議の第三部の 委員でほぼ構成されていたが、この委員会は、その趣旨から、第一部から第三部までの幅広い専 門家によって組織された。この委員会により、2019年9月に学術フォーラム「自動車の自動運転 の推進と社会的課題について一移動の本能と新しい社会のデザイン一」を開催した。このフォー ラムは、広い視点からの講演・パネル討論が行われ、大変好評であり、『学術の動向』にてきちん と記録すべきという意見を多数頂いた。以上の背景から、本特集では、このフォーラムの内容の 収録を基本とする一方で、内容をさらにアップデートして、自動運転と社会デザインについての 知見を広めることを目的として企画した。

日本学術会議第三部会員 芝浦工業大学名誉教授・SIT 総研特任教授 大倉典子 